\title{
Anti-Inflammatory Effects of Kaempferia galanga L. Rhizome Extract in Carrageenan-Induced Female Rats
}

\author{
$1^{\text {st }}$ Galih Samodra \\ Pharmacy Study Program, Faculty of Health Science \\ Harapan Bangsa University \\ Purwokerto, Indonesia \\ galihsamodra@uhb.ac.id
}

\author{
$2^{\text {nd }}$ Dina Febrina \\ Pharmacy Study Program, Faculty of Health Science \\ Harapan Bangsa University \\ Purwokerto, Indonesia \\ dinafebrina@uhb.ac.id
}

\begin{abstract}
Kencur (Kaempferiae galanga L.) is a plant that is traditionally used for the treatment of various diseases including inflammation. This study aimed to know the comparison of the effectiveness of kencur extracts with diclofenac sodium as an antiinflammatory agent. Fifteen female rats aged 2-3 months (200250 gram) were divided into 5 groups: rats in negative control group only given a $2 \%$ suspension of PGA, rats in positive control group given 20 $\mathrm{mg} / \mathrm{Kg}$ diclofenac sodium, and rats in three different dose groups given galanga rhizomes extract of 45,90 , and 180 $\mathrm{mg} / \mathrm{Kg}$, respectively. All drugs were given 1 hour orally before carrageenan injection of $1 \%$ as induction of edema. Edema volume was measured every 30 minutes to 390 minutes to calculate the percentage of edema inhibition. The data were analyzed using one-way ANOVA and followed by LSD test to see differences among groups. Ethanol extract of galanga rhizome in the 5th hour at doses of 45,90 and $180 \mathrm{mg} / \mathrm{kg}$ showed significant differences in a positive control group. Each Sig. value was $0.002 ; 0.004 ; 0.002$. This showed that the ethanol extract of kencur had anti-inflammatory activity at all dose levels.
\end{abstract}

\section{Keywords: Kaempferia galanga L., anti-inflammatory, carrageenan}

\section{INTRODUCTION}

Inflammation is linked to certain diseases that can be found in the community, usually characterized by swelling, pain, redness, and heat. The inflammation can be caused by a normal protective response to tissue injury from physical trauma, hazardous chemicals, or microbiological agents. Inflammation is a response of the body's efforts to activate or destroy invading organisms, remove irritants and prepare phases of the tissue repair process [1].

Kencur (Kaempferia galanga L.) is one of the herbal plants of the Zingiberaceae family which has many pharmacological activities [2]. Society in Indonesia traditionally uses kencur as medicine for inflammation of the stomach (gastritis), inflammation of the child's ear (ear infection), influenza in infants, colds, headache, cough, diarrhea, sore eyes, sprains, and fatigue. It is also used to get rid of dirty blood and get through periods smoothly. Previous studies reported that the extract of kencur has analgesic and anti-inflammatory effects [3], nematicidal agents [4], mosquito repellent and larvacidal effect [5], vasorelaxants [6], antineoplastics [7], antioxidants [8], and antimicrobials [9].

One of the plants that has an anti-inflammatory effect is kencur (Kaempferia galanga L.). The choice of appropriate extraction solvent is also important to obtain the best result of extraction efficiency and to obtain compounds that have pharmacological activities. The best solvent is ethanol or its mixture with water because it is a good extraction solvent for almost all low-molecular-weight compounds such as saponins and flavonoids. The type of extraction solvent also affects the number of active compounds in the extract based on the principle of "like dissolve like", in which polar compounds will dissolve in polar solvents and non-polar compounds will dissolve in non-polar solvents [10]. Ethanol is often used as a solvent in the laboratory because it is an inert solvent in which it does not react with other components [11].

In this study, the animals tested were rats because metabolism in the rats' body and humans are physiologically more similar and the structure of the tissue in the rats' feet is easier to be treated with subcutaneous induction compounds. Methanol and ethanol are both alcohol derivative solvents which have hydroxyl $(\mathrm{OH})$ groups and have carbon chains (atomic $\mathrm{C}$ ). The number of $\mathrm{C}$ atoms in ethanol is greater (two $\mathrm{C}$ atoms), and thus this compound can dissolve secondary metabolites that are non-polar in purslane plants. Other studies also mentioned that kencur rhizome extract at a dose of $45 \mathrm{mg} / \mathrm{kg}$ was able to show a very high percentage of inhibition compared to other dose groups and positive control $(51.27 \%)$ [12]. In this case, society has lack of information about Kaempferia galanga extract that functions as an antiinflammatory drug. This extract has a great potential, then society should exploit it. Based on this study, it is necessary to test various methods and comparisons. 


\section{METHODS}

\section{Anti-inflammatory test}

\section{A. Preparation for Animal experiment}

Before being used, rats were acclimatized for 1 week in a cage to adapt to a new environment. All rats were kept in the same conditions, given the same food and drink, and observed their general condition regularly, and weighed. Before the experiment, rats were deprived of food for \pm 18 hours but they still received water ad libitum [13]. Rats that were sick which had standing fur, were less active and had unclear eyes were excluded in this study. Fifteen rats were used and randomly divided into 5 groups consisting of 3 rats of each (referring to WHO provisions). The following is the description of the treatment given to each group of rats:

\begin{tabular}{|c|c|c|}
\hline Group & $\begin{array}{c}\text { Number } \\
\text { of rats }\end{array}$ & Treatment \\
\hline $\begin{array}{l}\text { Negative } \\
\text { control } \\
\text { group }\end{array}$ & 3 & $\begin{array}{l}\text { Have given the } 2 \% \text { PGA } \\
\text { suspension }+ \text { induced with } 1 \% \\
\text { carrageenan as much as } 0.1 \\
\text { mL }\end{array}$ \\
\hline $\begin{array}{l}\text { Positive } \\
\text { control } \\
\text { group }\end{array}$ & 3 & $\begin{array}{l}\text { Have given sodium diclofenac } \\
\text { at a dose of } 20 \mathrm{mg} / \mathrm{Kg} \text { in } 2 \% \\
\text { PGA + induced with } 1 \% \\
\text { carrageenan as much as } 0.1 \\
\mathrm{~mL}\end{array}$ \\
\hline Dosage I & 3 & $\begin{array}{l}\text { Have given a suspension of } \\
\text { test compound extract in } 2 \% \\
\text { PGA (dose } 45 \mathrm{mg} / \mathrm{Kg} \text { ) + } \\
\text { induced with } 1 \% \text { carrageenan } \\
\text { as much as } 0.1 \mathrm{~mL}\end{array}$ \\
\hline $\begin{array}{l}\text { Dosage } \\
\text { II }\end{array}$ & 3 & $\begin{array}{l}\text { Have given a suspension of } \\
\text { test compound extract in } 2 \% \\
\text { PGA (dose } 90 \mathrm{mg} / \mathrm{kg} \text { ) + } \\
\text { induced with } 1 \% \text { carrageenan } \\
\text { as much as } 0.1 \mathrm{~mL}\end{array}$ \\
\hline $\begin{array}{l}\text { Dosage } \\
\text { III }\end{array}$ & 3 & $\begin{array}{l}\text { Have given a suspension of } \\
\text { test compound extract in } 2 \% \\
\text { PGA (dose } 180 \mathrm{mg} / \mathrm{kg} \text { ) + } \\
\text { induced with } 1 \% \text { carrageenan } \\
\text { as much as } 0.1 \mathrm{~mL}\end{array}$ \\
\hline
\end{tabular}

B. Anti-inflammatory Activity Test using CarrageenanInduced Rats Paw Method (Winyard \& Willoughby, 2003; Winter et al, 1962; Morris, 2003)

The followings are the procedure of the experiment.

1. Rats were weighed and grouped randomly into 5 groups. Each group consisted of 3 rats.
2. Rats were acclimatized for 1 week to adapt to the experimental environment.

3. Before the experiment, rats were deprived of food for \pm 18 hours but still given drink.

4. At the beginning of the research, all rats were marked with markers at the ankle and therefore the foot was always the same when entered into the mercury.

5. The initial volume of rats' feet (paw) was measured before being treated and it represented the base paw volume (V0).

6. The negative control group was given a $2 \%$ suspension of PGA, while the positive control group was given a suspension of diclofenac sodium at a dose of $20 \mathrm{mg} / \mathrm{kg}$. The other three groups were given a suspension of the compound test according to the planned doses given orally.

7. One hour later rats were injected $0.1 \mathrm{ml}$ of $1 \%$ carrageenan by subplantar injection in the rats left leg. Before the carrageenan was injected, the area of the rats' paw was wiped with alcohol swabs.

8. Furthermore, edema volume was measured in the 30th, 60th, 90th, 120th, 150th, 180th, 210th, 240th, 270th, 300th, 330th, 360th, and 390th minute after induction using plethysmometer represented as the final volume $(\mathrm{Vt})$.

9. The percentage of edema and average (mean) percentage of edema inhibition was calculated using the following formula:

\section{Description :}

Vt: paw volume of rats at time $\mathrm{t}$ (after carrageenaninduced) V0: paw volume of rats at time 0 (before carrageenan-induced)

$$
\% \text { Edema inhibition }=\left(\frac{a-b}{a}\right) \times 100 \%
$$

Description

$\mathrm{a}: \%$ edema in negative control group $\mathrm{b}: \%$ edema in test group [14]

\section{RESULTS AND DISCUSSION}

In this study, the anti-inflammatory activity test of kencur rhizome extract was done by the Winter method (carrageenan induction). Carrageenan induction is the possible method to be analyzed after given a single dose of nontoxic in one day. Besides, this method is the most widely used as it is simple, easy, and suitable for testing the antiinflammatory activity of a compound in small amounts [15].

The use of carrageenan as edema induction in rats' feet has been widely used in testing the anti-inflammatory activity of a drug compounding $[16 ; 17]$. Edema formed by carrageenan induction is in the form of acute inflammation [18; 19]. Carrageenan was chosen in this study because it can trigger the release of prostaglandins after being injected in rats and therefore this compound can be used to find 
antiinflammatory drugs to inhibit prostaglandin synthesis [15]. Rats weighed 150-250 grams.

In this experiment, the animals tested were grouped into 5 in which each consisted of 3 rats (referring to WHO provisions). The experimental group consisted of a negative control group (2\% suspension of PGA), a positive control group (diclofenac sodium suspension at a dose of $20 \mathrm{mg} / \mathrm{kg}$ ), and dose test groups with varying doses of $45 \mathrm{mg} / \mathrm{kg}, 90$ $\mathrm{mg} / \mathrm{kg}$ and $180 \mathrm{mg} / \mathrm{kg}$.

The choice of dose varied referring to the research of Hasanah [12], in which the extract of kencur rhizome has the most optimal anti-inflammatory activity at a dose of 45 $\mathrm{mg} / \mathrm{kg}$. Tests were carried out using 3 dose variations, indicating the greater the dose given, the greater the antiinflammatory activity produced. The results showed a significant percentage of inhibition in treatments at a dose of $45 \mathrm{mg} / \mathrm{kg}$ and the percentage of inhibition was $51.27 \%$. Before the treatment, the basic volume of rats' foot (V0) was measured first and furthermore, rats' foot volume was measured every 30 minutes for 6.5 hours and it represented Vt.

The anti-inflammatory activity of a compound can be seen from its ability to inhibit the formation of edema in the rats' paw [19]. This was assessed from the increase or decrease in edema volume every 30 minutes. The edema volume was measured using a plethysmometer. The use of this tool required accuracy in the measurement because the volume of mercury always have to be the same in every test. Rats' feet were marked on the ankle joint and therefore the immersion of rats' feet into the mercury remained the same every 30 minutes. The edema volume of rats' feet was measured every 30 minutes for 6.5 hours. After carrageenan induction, the mean volume of edema was obtained and it can be illustrated in the following figure:

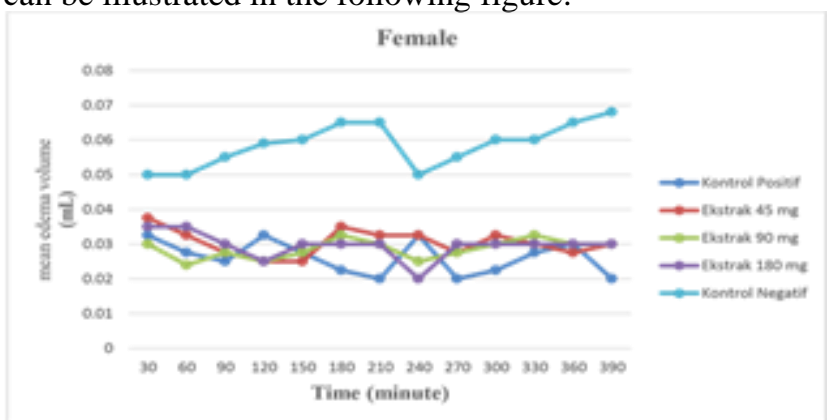

Figure 1. The edema volume in the 30th to 390th minutes.

From the graph of mean edema volume above, it can be seen the difference between the negative control group and the treatment group. The negative control group that was not given extracts and drugs has a significant increase compared with other treatment groups. The group which was not induced by carrageenan did not form edema at all and rats' feet do not show an increase or a decrease in edema volume. Unlike the group with no induction, the groups with carrageenan induction show an increase or a decrease in edema volume after induced by carrageenan. This shows that $0.1 \mathrm{~mL}$ of $1 \%$ carrageenan-induced could form significant edema and there were differences among test groups. The increase in edema volume was caused by the release of inflammatory mediators such as prostaglandins, histamine, bradykinin, and serotonin in tissues after carrageenan induction. Besides, the decrease in edema volume of each test group at the fifth hour was due to the effect of carrageenan which had begun to decrease. The formation of edema by carrageenan only lasts for 5-6 hours and gradually decreases within 24 hours after injection [20].

Furthermore, the percentage of edema formation from the edema volume of the rats' paw can be calculated to see the differences in edema between groups by using this formula: ( $\mathrm{Vt}-\mathrm{Vo}$ ) / Vo $\mathrm{x} 100 \%)$, which is $\mathrm{Vt}=$ Volume of edema every hour and $\mathrm{V} 0=$ volume rats' paw before the treatment. The results of the calculation of the mean percentage of edema on the rats' paw can be described as follows:

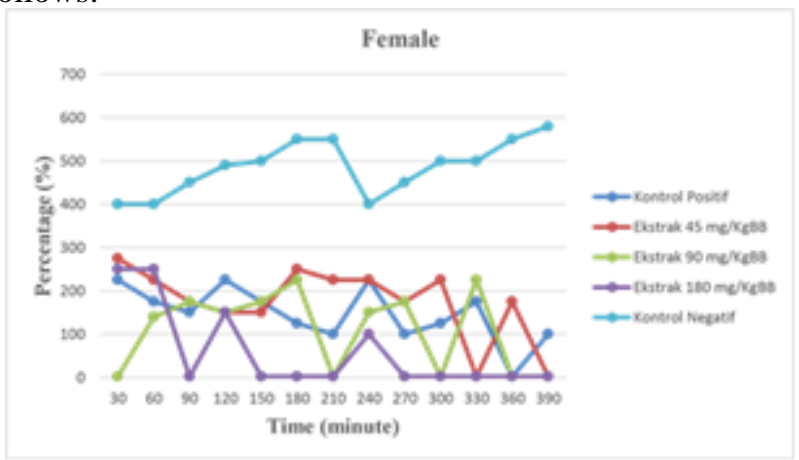

Figure 2. The graph of the relationship between mean percentages of edema and time (minute)

From the graph above, it can be seen that the negative control group has a very high percentage of edema formation and has a significant increase continuously to the 3rd hour. Then it begins to fall at the 4 th hour and rises again to the 6.5th hour. In this case, animals tested were only given a suspension of PGA that was unable to inhibit the formation of edema and the response to edema only relies on rats' immunity. Compared to the positive control group, the dose I, dose II and dose III of the edema volume were lower. Based on the results of the statistical tests, the four groups were significantly different compared to the negative control group ( $\rho>0.05)$. Thus, it can be concluded that these four groups have antiinflammatory activity in inhibiting the formation of edema in the rats' paw. Furthermore, the mean percentage of edema formation inhibition in each group can also be calculated to see the anti-inflammatory activity. It can be illustrated in figure 3 . 
in each group. The result showed a significant difference between the positive control group and the 45, 90, and 180 $\mathrm{mg} / \mathrm{kg}$ dose groups. This shows that the ethanol extract of kencur with doses of 45, 90, and $180 \mathrm{mg} / \mathrm{kg}$ has an antiinflammatory.

The edema formation process induced by carrageenan occurs in two phases and involves a variety of inflammatory mediators [22]. The first phase occurs for 3 hours after carrageenan induction in which histamine, serotonin, bradykinin are released and have an increase in prostaglandin synthesis around the injured tissue. The second phase occurs from the fourth hour to the fifth hour and there is an absorption of prostaglandins, proteases and lysosomes [22; 23; 24]. Generally, this second phase is sensitive to anti-inflammatory drugs [25].

In this study, the drug used in positive control was diclofenac sodium at a dose of $20 \mathrm{mg} / \mathrm{kg}$ showing the best percentage of edema inhibition. This is consistent with the literature that diclofenac sodium as an NSAID inhibits the nonselective cyclooxygenase enzymes, thereby it inhibits the release of prostaglandins [26]. Of the three dose groups, the dose II group $(90 \mathrm{mg} / \mathrm{Kg})$ has a high average percentage of inhibition compared to the other dose groups. In addition, the dose I and III (45 mg/kg and $180 \mathrm{mg} / \mathrm{kg}$ ) have the same average percentage of inhibition. From this study, a decrease in the dose of kencur rhizome extract compound increased edema inhibition ability in the rats' paw. This is because actually several types of drugs in high doses cause the release of histamine directly from mast cells causing blood vessels to be more permeable to plasma fluid and causing inflammation processes (immunological processes occur) [27].

sodium starting in 30 minutes after treatment and reaches peak at 390 minutes. The smallest percentage of inflammation inhibition is at a dose of $45 \mathrm{mg} / \mathrm{kg}$. Kencur ethanol extract at a dose of $90 \mathrm{mg} / \mathrm{kg}$ has a potential effect on edema inhibition. Certain ingredients can have antiinflammatory effects. It can be proved that swelling reduced by $50 \%$ or more when experimental animals were induced by carrageenan $1 \%$ [21].

The edema inhibition in each group was tested for its normality using the Kolmogorov Smirnov test. The data normality test was normally distributed. The homogeneity test was also applied which shows the value ( $p>0.05)$. This means the data varied homogeneously. The ANOVA test was performed to find out significant differences between the five groups. The ANOVA test result showed that Sig. value at the 5 th hour was 0.006 . It can be concluded that there were significant differences between the dose treatment groups and the positive control group. a further test was conducted using LSD to determine the differences

\section{REFERENCES}

[1] Harvey R. A. \& Pamela C.C., 2013, Farmakologi Ulasan Bergambar, Penerbit buku kedokteran: EGC, Jakarta.

[2] Umar, Muhammad Ihtisham., Mohammad Zaini Bin Asmawi., Amirin Sadikun., Rabia Altaf and

\section{CONCLUSIONS}

Ethanol extract of kencur rhizome extract in the 5th hour at doses of 45,90 and $180 \mathrm{mg} / \mathrm{kg}$ showed significant differences in the positive control group and each Sig. value was $0.002 ; 0.004 ; 0.002$. This showed that the ethanol extract of kencur rhizome had anti-inflammatory activity at all dose levels.

\section{ACKNOWLEDGMENTS}

The authors would like to express gratitude for the Dwi Puspita Educational Foundation of Harapan Bangsa University which funded this research.

Muhammad Adnan Iqbal. 2011. Phytochemistry and Medicinal Properties of Kaempferia galanga L. (Zingiberaceae) Extracts. African Journal of Pharmacy and Pharmacology Vol. 5 (14), (hlm: 16381647).

[3] Sulaiman, Mohd Roslan., Zainul Amiruddin Zakaria., IA Daud., Ng FN., Ng YC., Hidayat MT. 2008. Antinociceptive and Anti-inflammatory Activities of 
the Aqueous Extract of Kaempferia galanga Leaves in Animal Models. Journal of Natural Medicines, 62(2), (hlm: 221-227).

[4] Hong, Tae-Kyun., Kim Soon-Il., Heo Jae-Won., Lee Jae-Kook., Choi Dong-Ro., Ahn Young-Joon. 2011. Toxicity of Kaempferia galanga Rhizome Constituents to Meloidogyne Incognita Juveniles and Eggs. Nematology, 13(2). (hlm: 235-244).

[5] Sutthanont, Nataya., Wej Choochote., Benjawan Tuetun., Anuluck Junkum., Atchariya Jitpakdi., Udom Chaithong., Doungrat Riyong and Benjawan Pitasawat. 2010. Chemical Composition and Larvicidal Activity of Edible Plant- Derived Essential Oils Against the Pyrethroid-Susceptible and Resistant Strains of Aedes aegypti (Diptera: Culicidae). Journal of Vector Ecology, 35(1), (hlm:106-115).

[6] Othman, Rozana., Halijah Ibrahim., Mohd Mustafa Ali., Muhammad Rais Mustafa., Khalijah Awang. 2006. Bioassay-Guided Isolation of a Vasorelaxant Active Compound from Kaempferia galanga L. Phytomedicine, 13(1-2), (hlm: 61-66).

[7] Liu B., Liu F., Chen C., Gao H .2010. Supercritical Carbon Dioxide Extraction of Ethyl pMethoxycinnamate from Kaempferia galanga L. Rhizome and its Apoptotic Induction in Human HepG2 cells. Natural Product Research, 24. (hlm: 1927-1932).

[8] Mustafa RA., Abdul HA., Mohamed S., Bakar FA. 2010. Total Phenolic Compounds, Flavonoids and Radical Scavenging Activity of 21 Selected Tropical Plants. Journal of Food Science, 75(1), (hlm: C28C35).

[9] Kanjanapothi, Duangta., Panthong A., Lertprasertsuke N., Taesotikul T., Rujjanawate C., Kaewpinit D., Sudthayakorn R., Choochote W., Chaithong U., Jitpakdi A., Pitasawat B. 2004. Toxicity of Crude Rhizome Extract of Kaempferia galanga L. (Proh Hom). Journal of Ethnopharmacology, 90 (2-3). (hlm: 359-365).

[10] Arifianti susanti, Oktarina, R.D., Kusumawati, I, 2014, pengaruh jenis pelarut pengektraksi terhadap kadar sinensetin dalam ektrak daun orthosiphon stamineus benth. E-Journal Planta Husada; 2 (1).

[11] Susanti Ari D., Ardiana dwi, Gumelar Gita P., Bening Yoshepin B., 2012, Polaritas Pelarut sebagai pertimbangan dalam pemilihan pelarut untuk ekstraksi minyak bekatul dari bekatul varietas ketan (Oriza sativa Glatinosa), Simposium Nasional RAFI FT UMS-2012, ISSN 1412-9612.

[12] Hasanah A. N., Fikri N., Ellin F., dan Ade Z. Analisis Kandungan Minyak Atsiri dan Uji Aktivitas Antiinflamsi Ekstrak Rimpang Kencur (Kaempferiae galanga L.). Jurnal Matematika \& Sains. 2011;16(3):147-152.

[13] Sukaina, Ira. 2013. Uji Efek Antiinflamasi Herba Kemangi (Ocimum americanum Linn.) Terhadap Udema Pada Telapak Kaki Tikus Putih Jantan Yang Diinduksi Karagenan. Skripsi. Progam Studi Farmasi, UIN Syarif Hidayatullah Jakarta. (hlm: 21-22).

[14] Mohan, Neha. P. V., Suganthi. V., Gowri. S. 2013. Evaluation of antiinflammatory activity in ethanolic extract of Coriandrumsativum L. using carrageenan induced paw oedema in albino rats. Der Pharma Chemica, 5(2), (hlm: 139-143).

[15] Winter, C. A., Risley, E. A., and Nuss, G. W. 1962. Carrageenan induced oedema in hind paw of the rats as an assay for anti-inflammatory drugs. Proc. Soc. Exp. Bio Med, 111. (hlm: 544-547). Winyard, Paul G. \& Derek A.Willoughby. 2003. Inflammation Protocols. Totowa, New Jersey: Humana press. (hlm: 120).

[16] Rowe, Raymond C., Paul J Sheskey and Marian E Quinn. 2009. Handbook of Pharmaceutical Excipients sixth edition. UK: Pharmaceutical Press and American Pharmacist Association. (hlm :118-121).

[17] Petersson M, Wiberg U, Lundeberg T, Uvnas-Moberg K. 2001. Oxytocin decreases carrageenan induced inflammation in rats. Peptides 22, (hlm: 1479-1484).

[18] Singh, Amritpal., S. Maholtra., \& R. Subban. 2008. Antiinflamatory and Analgesic Agents from Indian Medicinal Plants. International Journal of Inegrative Biology, 3 (1), (hlm: 57-72).

[19] Agbaje E.O., Fageyinbo M.S. 2012. Evaluating AntiInflammatory activity of aquous root extract of Strophantus hispidus DC. (Apocynaceae). International Journal of Applied Research in Natural Products Vol. 4 (4), (hlm: 7-14).

[20] Hidayanti, Nur Annis., Listyawati, Shanti., Setyawan, Ahmad Dwi. 2008. Kandungan Kimia dan Uji

Antiinflamasi Ekstrak Etanol Lantana camara L. pada Tikus Putih (Rattus norvegicus L.) Jantan. FMIPA UNS Surakarta. Bioteknologi 5 (1). (hlm: 10-17).

[21] Ira Sukaina. 2013, Uji Efek Antiinflamasi Ektrak Etanol Herba Kemangi (Ocimum Americanum Linn) Terhadap Udem Pada Telapak Kaki Tikus Putih Jantan Yang Diinduksi Karagenan. Skripsi, Fakultas Kedokteran dan Ilmu Kesehatan Program Studi Farmasi Jakarta.

[22] Necas, J., L. Bartosikova. 2013. Carrageenan: a review. Veterinarni Medicina, 58(4), (hlm: 187-205). [23] Asongalem E.A., Foye H.S., Ekobo S., Dimo T. dan Kamtchouing P. 2004. Antiinflammatory, lack of central analgesia and antipyretic properties of Acanthus montanus (Ness) T. Anderson. Journal of Ethnopharmacology 95 (hlm: $63-8$ ).

[24] Silva G.N., Martins F.R. and Matheus M.E. (2005). Investigation of antiinflammatory and antinociceptive activities of Lantana trifolia. J Ethnopharmacol 100, (hlm: $254-259$ ).

[25] Onasanwo S.A., Fabiyi T.D., Oluwole F.S., Olaleye S.B. 2012. Analgesic and anti-inflammatory properties of the leaf extracts of Anacardium occidentalis in the laboratory rodents. Niger J Physiol Sci. 7; 27(1), (hlm: 65-71).

[26] Rao, Praveen P.N., Kabir, Saad N., Mohamed, Tarek. 2010. Nonsteroidal AntiInflammatory Drugs (NSAIDs): Progress in Small Molecule Drug Development. Pharmaceuticals 3, (hlm: 1530-1549).

[27] Kurniawati, A. 2005. Uji Aktivitas Anti Inflamasi Ekstrak Metanol Graptophyllum griff pada Tikus Putih. Majalah Kedokteran Gigi Edisi Khusus Temu Ilmiah Nasional IV, (hlm: 167-170). 